\title{
THE EFFECTIVENESS OF ONE-STOP SERVICE POLICY IN \\ PROTECTING THE RIGHTS OF INDONESIAN MIGRANT \\ WORKERS IN TULUNGAGUNG
}

\author{
Tutik SULISTYOWATI (i) 1* \\ Iradhad TAQWA SIHIDI (iD) 2 \\ Nuryu WAHIDAH (i) 3 \\ 1 University of Muhammadiyah Malang, Faculty of Social and Political Sciences, tutiksulistyowati@umm.ac.id *Corresponding Author \\ 2 University of Muhammadiyah Malang, Faculty of Social and Political Sciences, iradhad@umm.ac.id \\ 3 University of Muhammadiyah Malang, Faculty of Social and Political Sciences, iradhad@umm.ac.id
}

\author{
Article history: \\ Submission 17 November 2020 \\ Revision 25 November 2020 \\ Accepted 14 January 2021 \\ Available online 30 April 2021
}

\section{Keywords:}

Policy Effectiveness,

One-Stop Integrated Services,

Prospective Migrant Workers.

DOI:

https://doi.org/10.32936/pssj.v5i1.199

\begin{abstract}
A b s t r a c t
The Indonesian government has tried to protect migrant workers, one of which is through Law no. 18 of 2017 concerning protecting the rights of migrant workers in an integrated manner. This research aims to examine how this policy's effectiveness in protecting the rights of Indonesian migrant workers in Tulungangung Regency. This research uses descriptive research with a qualitative approach. The research findings show that one-stop service helps prospective workers manage all documents quickly and easily and is efficient in terms of costs and labor, and providing skills and attitude for working capital. One-stop integrated service policy implemented in the Tulungagung local government is based on the PTKLN Law No. 18 of 2017, Also, as an excellent service standard (SPM) according to the Decree of the Minister of Home Affairs No. 6/2007, that is simple, apparent, legal certainty, accurate, safe, responsible, complete facilities, and infrastructure, easy access, discipline, friendly, polite and comfortable in providing services.
\end{abstract}

\section{Introduction}

regulating and fulfilling the rights of migrant workers as stipulated in the Overseas Migrant Workers Protection Law No. 18 of 2017 is a form of paradigm shift of the government in serving the public better (Undang-undang RI., 2017). The impression of an authoritarian and centralized government has turned into a decentralized government and has an entrepreneurial spirit, as a change in service orientation in improving public services quality (Ismayanti, 2015). Policymakers sometimes act as bureaucrats by making regulations that are not relatable with the public needs to address the root causes of problems (Suphanchaimat, Putthasri, Prakongsai, \& Tangcharoensathien, 2017). Various public service innovation breakthroughs are currently being promoted from several parts as a form of government commitment to improving service quality (Rinda Paradista, 2019). So far, the service policy for migrant workers as both prospective and full-time workers is a service that requires a person to visit many places or offices and many desks, thus allowing a potential worker to lose much time, energy, and practice of bribery. This one-stop integrated service policy is intended to cut the bureaucratic chain and save time and energy. Moreover, the current digital era allows public services to be carried out using an e-government system (a government system based on communication technology).

Although Online Single Submission successfully registering a large number of migrant worker documents, utilization of functions between ministries in different integrated services is not yet totally integrated into one service, and there is still a lack of comprehensive support mechanisms to address issues of workers' rights and legal status migrant (Suphanchaimat et al., 2017). The implementation of human rights protection in a country cannot be separated from the existence of a legal product or regulation made in advance to protect human rights by legal regulations (Liunsanda, 2019; Mihradi \& Siregar, 2017; Nola, 2016). Every person carrying out their work is entitled to fair and proper 
compensation and treatment (Nola, 2016). Therefore, the right to work is a human right inherent in a person that must be upheld and respected (Taufik, 2014). For the community of Indonesian migrant workers abroad, information technology in social helps social relations that have been far between them and their families, including obtaining services and protection from the government. Migrant worker rights regulations have been widely regulated in international law and national law (Liunsanda, 2019). Services and protection of the rights of Indonesian migrant workers abroad can begin to be provided with digital systems, such as identity card services, population administration services, travel document services, insurance payments, consultation on work issues. This service can be done both domestically and abroad.

As one of the senders of migrant workers, Indonesia facilitates integrated services through digital technology. Data from BNP2TKI in 2018, currently the number of Indonesian migrant workers is 9.5 million people (only approximately 6.5 million who depart according to procedures, the rest are non-procedural). The low income in the family economy and the burden of dependence on the agricultural sector causes individuals to decide to work as migrant workers (Herawati, 2010; Irawaty \& Sri Wahyuni, 2015; Sulaiman, Sugito, \& Sabiq, 2017). As for Indonesians, the motivation to become a migrant worker mainly caused by the insufficient income from farming, has triggered households to seek additional income from outside of agriculture. The factors of higher income, low employment opportunities. The factors of higher income, low employment opportunities, and the influence of relatives' or friends' success after working abroad are the causes of migrant workers (Sulistyowati, 2009). From the reality that many Indonesians become migrant workers abroad, Indonesia has a high foreign exchange. Until 2018, Indonesia's foreign exchange from this sector was 153.6 trillion rupiahs (Bank Indonesia, 2018). Of course, this effect must be balanced with the adequate skills of migrant workers.

Behind the success of migrant workers, some of them experience failure, either before leaving, while working or after returning to Indonesia. Failure can arise when the actors in it create problems (Hartono Widodo, 2019). Some of the contributing factors are the lack of mental readiness of workers, minimum skills, minimal knowledge of the country of destination, and workers' inability to construct themselves with the culture in the workplace (Sulistyowati, 2019). Apart from problems concerning migrant workers' personalities and administration problems, there is no permit letter from the village, and personal data is fabricated by irresponsible officers (Sulistyowati, 2019). The government's task is not only to regulate but also to provide services to the community (Layaman \& Hartati, 2009). The problems related to administration and services from the government, while problems related to migrant workers are determined by the ability and readiness of migrant workers themselves. (Sulistyowati, 2019).

The inability to build social relations with the destination country's work environment is the basis for new problems in the destination country. Cultural issues, communication, and several customs in different countries have a more significant impact on their safety as workers abroad (Asriani \& Amalia, 2016). The research result on the construction of the identity of migrant workers in destination countries (Sulistyowati, 2019) shows the low ability of migrant workers to develop themselves as migrant workers is the first cause of problems in the country of work. The ability to construct themselves as migrant workers is visible in the lack of ability to communicate and adapt to the destination country's culture.

From the reality of low self-efficacy and the problems that arise from migrant workers, it is necessary to instill and equip them with the right to get a job abroad and choose a job according to their competence (Hartono Widodo, 2019) and fundamental rights of migrant workers. The majority of Indonesian migrant workers do not understand their rights, so the problem is not resolved. The protection of the rights and dignity of migrant workers and their families depends on each receiving country's regulations and policies (Taufik, 2014). Several research and information findings suggest that migrant workers often act in ways irrational, provocative, and emotionally unstable (Cheng, 2016).

In suppressing Indonesian migrant workers' problems, the government, through UU PTKLN No. 18 of 2017 CHAPTER IV Article 38 concerning One-Stop Services, undertakes efforts to protect the rights of migrant workers. Protection of rights through this one-stop service implemented by an office, where people who need assistance can be done at the office to function as frontline and as a backline (Ginting, Susanti, \& Sumaryana, 2018). This policy is an integrated service effort in protecting the rights of migrant workers regarding population administration, validating identity cards, good behavior letters from the police, payment for departure administration, and the Final Departure Briefing (PAP), the service process is initially carried out by the relevant agencies, so that takes a long time.

However, the effectiveness of protecting the rights of migrant workers needs to be seen, given that there are still problems in the services of migrant workers. The one-stop integrated policy is a form of a government effort to cut the chain of issues for migrant to protect prospective workers from beginning to end. This article results from research on the effectiveness of one-stop services in 
protecting the rights of migrant workers in Tulungagung Regency.

\section{Literature Review}

\subsection{Integrated Public Service}

The concept of public service is the fulfillment of people's wants and needs by state administrators and the state established by the public to improve the community's walfare (Ismayanti, 2015). Each individual has a difference in responding to public services because it has to be adjustable between supply and demand, according to their needs (Ouyang, Wang, Tian, \& Niu, 2017). As a state apparatus, the government must be able to provide adequate public services to the community (Enggarani, 2016). Public service is categorized to be effective if it is by the goals and objectives of public service delivery, namely community satisfaction. Services that have to be accomplished are short, fast, straightforward, and correct regarding the process passed in applying for a license (Suhayati, 2017). According to Drucker in (Moenir, 2010) definition of effectiveness, "Effectiveness, on the other hand, is the ability to choose appropriate objectives. An effective manager is one who selects the right things to get done".

Public services are a measure of implementing tasks and measuring government performance through the bureaucracy (Maryam, 2016). To improve public service quality, the government began in 1997 to improve public service management by developing an integrated service system. The implementation of One-Stop Integrated Services, which emphasizes the implementation of licensing and non-licensing activities whose management process from the application stage to the issuance stage of documents carried out in one place.

According to Trochidis (2008), it is necessary to develop a model of public service institutions that can make it easier for the public and business community to deal with the government in public services (Ginting et al., 2018). One of the concepts developed is a service model that integrates various government services in one location, which is called one-stop service or one-stop government. The one-stop service or one-stop government model is integrating public services from the point of view and interests of the public or customers (Ginting et al., 2018). Public services are an essential aspect of protecting and improving people's welfare (Ismayanti, 2015). Public service organizations must be managed and possible to provide good service (Ginting et al., 2018).

\subsection{One-Stop Integrated Services (PTSA)}

\section{Policy}

The One-Stop Service Policy (PTSA) is a policy based on the Guidelines of Law (UU) No. 25 of 2009 concerning Public Servants with Minister of Manpower Regulation number 30 of 2015, concerning One-Stop Integrated Services, where each city or district government may organize PTSA. PTSA definitively is a service designed to be implemented in one place / one room by combining several types of services and several work units. To provide services jointly from the application stage to the service product completion stage (Permenaker RI. No. 30 Tahun 2015 tentang PTSA, 2015). It can be said that the One-Stop Integrated Service (PTSA) is one of the government programs to improve public services by cutting the bureaucracy of licensing and nonlicensing services and as an effort to achieve good governance or good governance. Meanwhile, PTSA aims to provide licensing and non-licensing fast, effective, efficient, transparent, and provide legal certainty and realize the public and investors' rights to obtain licensing services in the field.

The approach used in PTSA is a systems approach, with an effort to operate the One-Stop Integrated Services policy. The integrated approach is a system, but independents connect the policy actors' lines in its implementation. Bureaucratically, services like this can cause irregularities in implementing a component, and the impact on the other features is not immediately known. A one-stop approach is an approach that connects policy actors but also creates new problems in the exercise of virtue (RIZAL, 2008)

After the decentralization policy in 1999, several local governments experimented and innovated in developing various licensing services patterns so that regulations were made, which were given the implementation of the one-stop policy. However, there are obstacles in implementing the one-stop policy. In general, these constraints can be inventoried, among others:

1). Inconsistent and accommodating government regulations tend to confuse the public. Not all regional heads are willing to delegate authority to appointed officers.

2). Licensing services still tend to be unpredictable, slow, and not transparent, meaning that human resources have not fully supported the One-Stop Integrated Service (PTSA) policy.

$3)$. Sometimes the political and security situation and conditions in the country are inadequate and unpredictable.

4). The implementation of regional autonomy, which impacts on one-stop services, does not yet have a clear direction and tends to create new governments at lower levels. 
The one-stop service is still a trial that has not made a certainty to the community from the aforementioned constraints. Studies conducted by the World Bank show that the Indonesian bureaucracy is very complicated, starting from initiating, processing permits, land, export-import, and processing tax payments (RIZAL, 2008). According to the PTSA Law, 26 types of permits and non-permits can be handled in the One-Stop Integrated Service (PTSA). Licensing for migrant workers is one type of service, namely human resources and transmigration, therefore the authority rests with the human resources and Transmigration Office (Disnakertrans) in each city and district government. The concept of one-stop service (one roof system) is an administrative system that is formed to facilitate and accelerate services for the interests of the community whose activities are carried out in one building. This model aims to simplify services to the community, both licensing and non-licensing, the management process starts from the application process to the publication of documents.

\subsection{Basic Rights of Migrant Workers}

In general, the fundamental rights of workers are the right to develop work potential. Those are interests, talents, and abilities; the right to work security, health, and safety; the right to a decent wage; the right to vacation, leave and rest and restrictions on working time; and the right to form trade unions. However, workers' basic rights are slightly different from the basic rights of migrant workers because the system and nature of work have other characteristics from workers in general. Legal protection for workers aims to guarantee workers' basic rights and ensure equality and treatment without discrimination on any basis to realize the welfare of workers and their families (Nola, 2016).

In the Law on Placement of Overseas Workers (PTKLN), number 39 of 2004 has been revised in law no. 18 of 2017 concerning the protection and placement of migrant workers, states that every Prospective Indonesian Migrant Worker or Indonesian Migrant Worker has the right to 1) Get a job abroad and choose a job according to his / her competence; 2) Obtain access to the selfcapacity building through education and job training; 3) Obtain correct information regarding the labor market, procedures for placement, and working conditions abroad, verified by the labor attaché and foreign service officials appointed from; a. Representative of the Republic of Indonesia in the destination country of placement; b. Business Partners in the destination country of order; (must be verified by a labor attaché and/or appointed foreign service official) and/or prospective employers, both individuals and foreign business entities in the country of destination of placement. 4) Receive professional and human services and treatment without discrimination before work, during work, and after work; 5) Performing worship in accordance with the religion and belief; 6) Receive wages in accordance with the applicable wage standards in the destination country of placement and / or an agreement between the two countries and / or the Work Agreement; 7) Obtain protection and legal assistance for actions that can degrading dignity in accordance with the provisions of the laws and regulations in Indonesia and in the destination country of placement; 8) Obtain an explanation of the rights and obligations as stated in the Work Agreement; 9) Gaining access to communication; 10) Mastering travel documents while working; 11) Association and assemble in the destination country of placement in accordance with the provisions of laws and regulations in force in the destination country of placement; 12) Obtaining a guarantee of safety and security for the return of Indonesian Migrant Workers to their areas of origin; and / or Obtaining documents and employment agreements for Prospective Indonesian Migrant Workers and / or Indonesian Migrant Workers. 12) Obtaining a guarantee of safety and security for the return of Indonesian Migrant Workers to their areas of origin; and/or Obtaining documents and employment agreements for Prospective Indonesian Migrant Workers and/or Indonesian Migrant Workers. 12) Obtaining a guarantee of safety and security for the return of Indonesian Migrant Workers to their areas of origin; and/or Obtaining documents and employment agreements for Prospective Indonesian Migrant Workers and/or Indonesian Migrant Workers.

The rights mentioned above are the government's authority and related institutions in instilling and disseminating them to Indonesian Migrant Workers before leaving for work in the destination country to and understand and information about guarantees if they face problems in the country of employment. In the local government, the state must ensure that its citizens get services of a certain quality and standard through various regulations. Guarantee to get certain quality and service can use the minimum service standards. These minimum service standards are implemented to achieve goals, including providing a clear definition of services, providing information to carry out planning, and providing services to the community at the local level (Palmira Permata Bachtiar, Justin Sodo, 2013).

\section{Research Methods}

The effectiveness of the one-stop integrated service policy in protecting the rights of migrant workers is the result of research using a qualitative approach with descriptive analysis. This type of descriptive research has the characteristics of describing and explaining the observed phenomena, so this research explains the phenomenon of the effectiveness of the one-stop integrated service policy in protecting the rights of migrant workers. The research location was in the local government of Tulungagung Regency because Tulungagung had implemented a one-stop 
integrated service policy. The data obtained from the Head of the Tulungagung Regency Disnakertran, officers from the Civil Service Office, BRI Bank, Immigration, BNP2TKI Tulungagung, the Health Office, and the Police which are one-stop service institutions in Tulungagung.

The method in data collection is to use the interview method and supported by documentation and observation. The research conducted using a naturalistic research ideology. Research carried out naturally and holistically, and not using the trinity principle, the quantitative research tradition's validity, reliability, and generalizability. The trinity principle in qualitative research will keep one's 'life experience' (experience) from a person's 'knowing activity' (Janesick, 1998). In this principle, qualitative research relies on a solid descriptive presentation of data so that researchers can provide readers with an understanding of the subject's experiences under study.

The validity of qualitative research data has a micro definition that is technical in determining the subject and data collection and has a relationship with description and explanation. However, according to Lincoln \& Guba (1985), qualitative researchers can cross-check research findings with participants and audit steps (Janesick, 1998). In making the narrative report, the qualitative researcher can use an outsider as the reader to check with field notes and interview transcripts. This study used cross-checks (triangulation) between subjects and appointed an outsider to provide suggestions and input.

\section{Result and Discussions}

Based on Law No. 18 of 2017 CHAPTER IV Article 38 concerning One-Stop Services for the Placement and Protection of Indonesian Migrant Workers, it is said that the Central Government and Regional Governments carry out the placement and protection of Indonesian Migrant Workers in a coordinated and integrated manner in providing placement and protection services. The objectives of establishing one-stop integrated services include a). Realizing the effectiveness of the provision of placement and protection benefits for Indonesian Migrant Workers, b). Providing efficiency and transparency in processing placement documents and protection for Prospective Indonesian Migrant Workers and/or Indonesian Migrant Workers, c). Accelerate improving the quality of services for Indonesian Migrant Workers (Undang-undang RI No. 18 Tahun 2017 Tentang Perlindungan Pekerja Migran Indonesia, 2017)

According to the results of an interview with the Head of the Tulungagung Manpower Office, the protection of migrant workers in Tulungagung includes institutional protection, which regulates the duties and authorities of the work unit as implementing policies. The interview results stated that this protection is actually by the mandate of law number 18 of 2017 concerning one-stop integrated services. The duty of protecting Indonesian Migrant Workers is carried out by the Agency formed by the president, namely the National Agency for Placement and Protection of Migrant Workers (BNP2TKI) which is carried out starting from the village, district/city, and province, from before working until after work. Local governments play a role in providing job orders from Representatives of the Republic of Indonesia, employers, and business partners in the destination country.

Furthermore, according to Kadisnaker, in providing one-stop integrated services and facilitating the departure and return of Indonesian Migrant Workers, the Regional Government has the authority to prepare competencies or expertise for prospective migrant workers. Likewise, after work, the Regional Government, in collaboration with the Central Government, provides entrepreneurship training to full-time Indonesian Migrant Workers and their families. One-stop integrated services offer services in handling document requirements and placement administration and protecting prospective workers and the Central Government from recruiting and preparing administrative requirements services.

From the results of field observations, as well as interviews with the Head of the One-Stop Integrated Service (PTSA) office of Tulungagung Regency, The institutions incorporated in PTSA, based on Law No. 18 of 2017 CHAPTER IV Article 38 include: Employment Service (DISNAKER), Population and Civil Registry Service (DISPENDUK CAPIL), Health Service (DINKES), Immigration, BPJS Ketenagakerjaan, Placement and Protection of Indonesian Workers (PPTKI), POLRES, and Banks (Undang-undang RI No. 18 Tahun 2017 Tentang Perlindungan Pekerja Migran Indonesia, 2017). Still, according to the Head of the PTSA office in Tulungagung Regency, protection services for migrant workers are carried out based on the provisions of the law and pay attention to community satisfaction, especially prospective migrant workers.

The aspect of community satisfaction in obtaining one-stop service is the main factor so that efficiency, effectiveness, cheap, easy, comfortable can be obtained by the user community, namely, prospective migrant workers. According to observations, if the quality of work services is improved, satisfaction will increase (Sofiyan, 2018). As explained earlier, service is said to be effective if it is by excellent service standards, namely simplicity, clarity, legal certainty, accuracy, security, responsibility, completeness of facilities and infrastructure, easy access, discipline, politeness and friendliness, and comfort. The 
authorities in implementing the one-stop integrated service policy in Tulungagung are well aware that the services provided help prospective workers who need travel documents quickly and without being complicated. As stated by an officer from the health department, that the health check is carried out at the PTSA office, and if it meets the Health standards, the applicant can immediately obtain health documents.

Based on the research results, the institutions incorporated in onestop integrated services in protecting the rights of migrant workers in Tulungagung Regency provide services, those are: 1). Workforce Training Institute Permit. This license is given to private training institutions that provide training, namely individual institutions, foundations, and Limited Liability Companies that provide training for workers. 2). AK-1 card issuance, as a job seeker registration card. 3). Issuance of Prospective Indonesian Migrant Workers (CPMI) ID Card. 4). Providing Passport Recommendations for Prospective Indonesian Migrant Workers. 5). Granting permission to accommodate PPTKIS. 6). PPTKIS Branch Office Recommendation Services. 7). Registration Services for Workers / Labor Unions. 8). Service for Ratification of Company Regulations.

According to data from the PTSA Tulungagung office during 2017, The Tulungagung Regency One-Stop Integrated Service Office has provided integrated services to prospective overseas job seekers as follows:

Table 1. Users of PTSA Services in Tulungagung Regency in 2017

\begin{tabular}{|l|l|r|}
\hline & \multicolumn{1}{|c|}{ Kind of service } & \multicolumn{1}{|c|}{ Service } \\
\hline 1. & Workforce Training Institute Permit & 3 \\
\hline 2. & AK-1 card & 4,611 \\
\hline 3. & $\begin{array}{l}\text { ID of Prospective Indonesian Migrant } \\
\text { Workers }\end{array}$ & 3,830 \\
\hline 4. & $\begin{array}{l}\text { Prospective Worker Passport } \\
\text { Recommendations }\end{array}$ & 2,759 \\
\hline 5. & Permit to accommodate PPTKIS & 14 \\
\hline 6. & $\begin{array}{l}\text { Recommendations for PPTKIS Branch } \\
\text { Offices }\end{array}$ & 3 \\
\hline 7. & Registration of Workers / Labor Unions & 0 \\
\hline 8. & Ratification of Company Regulations & 3 \\
\hline 9. & $\begin{array}{l}\text { BIPARTIT Work Institution } \\
\text { Registration }\end{array}$ \\
\hline & amount & 11,225 \\
\hline
\end{tabular}

Source: Data from PTSA Office recap in 2017

From the table above, through the one-stop integrated service office, most of overseas job seekers are looking for AK-1 cards, identity cards for Indonesian Migrant Workers, and passport recommendations. This data shows that prospective migrant workers in Tulungagung are prospective workers in the formal sector, industry. As one prospective worker told the researcher, he was looking for a job in the automotive assembly industry in Taiwan, so he needed documents that were fast and easy to handle, and is a one-stop service office, he got that service quickly and easily for just one week all the letter has been obtained according to him.

According to interview data with the Head of Manpower Office, the ratio between formal and informal migrant workers in Tulungagung is $60 \%$ formal and $40 \%$ informal. In this aspect, it seems that prospective workers in Tulungagung have a different tendency from some surrounding areas in choosing the type of work in the destination country, for example, Blitar, Malang, and Trenggalek. These three regions are prospective migrant workers, preferring to prefer non-formal types, namely domestic work in the destination country. This reality must be maintained because local governments must consider worker skills to compete with prospective workers from other countries in the destination country.

In practice, the one-stop integrated service policy, the agency classifies the placement of workers according to the location of the order, which consists of local workforce (AKL), interregional workforce (AKAD), and inter-state labor force (AKAN). Data from the Tulungagung Disnaker for 2017, the number of the Inter-State workforce (AKAN) is 3,861 people, the total local workforce (AKL) is 1,710 people, and the inter-regional workforce (AKAD) is empty. Of the entire workforce of Tulungagung district, which amounted to 5,571 people in 2017, most preferred to work overseas (AKAN) rather than working in the local sector. Income factor is the main reason, choosing to work abroad compared to working locally.

To meet prospective overseas migrant workers' eligibility, they must meet several requirements set by the Indonesian Worker Placement and Protection Service Center (BP3TKI). This center is a technical implementation unit of BNP2TKI whose task is to provide easy services in placing and preparing all TKI documents. Prospective migrant workers must provide documents in the form of Passport and Work Visa, Placement Agreement, Work Agreement, Proof of Insurance Premium Payment, Certificate of Health Examination Results, Certificate of Skills from BLKN, Certificate of Competency Test, and certificate of SLC (Standard Labor Contract). In a one-stop service system, these documents are the priority of the service in providing services.

From the interview with prospective migrant workers about their understanding of rights when in the destination country, they mostly said that they already knew from the manual for prospective migrant workers. In general, they see the right to 
obtain visits from family members, keep personal documents (passports and work permits), obtain legal protection, raise problems with officials, get assistance and government representatives in the destination country, can move to another country, have access to labor information, obtain a work contract, which contains clear work conditions and employment information, receives fair treatment at work, obtains sufficient accommodation based on the laws, regulations, and national policies of the host country, obtain adequate and fair benefits and income, can remit income, gather and associate with groups of workers. Workers' rights are usually ignored by workers so that if a problem occurs in the destination country, they do not know the solution. Migrant workers as a social group, positioned as a foreign worker relation, tend to be oppressed and marginalized in terms of expressing individual desires as foreign nationals in the country of placement (Cheng, 2016), so that they need to obtain the protection of their rights legally.

Public services can to be useful if they are by the goals and objectives of providing public services. The Tulungagung Regency government human resource office provides services by the SOP for each agency, especially services related to the administration of Prospective Overseas Migrant Workers' documents. The Tulungagung Regency Disnakertrans provides a one-stop service with a service system 2 times a week, and in one day, it provides services for about 40 to 60 people.

According to research data, agencies that are directly related to filing documents of prospective migrant workers who are in the One-Stop Integrated Service of Tulungagung Regency include:

1). Dispenda, the Revenue Service serve if there is a problematic NIK, it will be straightened out according to the legality of the KTP and KK, issued by Dukacapil,

2) The Manpower and Transmigration Office provides ID card creation services and Passport recommendations, PPTKIS Accumulation permits for Indonesian Worker Training Implementation companies, provides guidance to PPTKIS Branch Offices that already have a business license from the government, and registers as job seekers

3) The Health Office, provides health certificate issuance services,

4) Immigration, provide Passport and Work Visa Issuance services, and work business documents.

5) Police, serving SKCK Issuance,

6) Banks (BRI) provide savings and loans and money transfer services, by providing services for issuing accounts, providing loans with installment payment and cash payment models, KUR (People's Business Credit) worth 3,000,000 rupiahs.
7) BPJS Ketenagakerjaan provides insurance services. Migrant workers who have a 2-year work contract are required to pay insurance costs 370 thousand rupiahs.

8) BNP2TKI, provides services for making KTKLN (Overseas Work Identity Cards) and fermentation of Final Departure Provisioning Documents (PAP).

The public service model carried out by the Tulungagung Regional Government with a one-stop integrated service system aims to facilitate the community, especially prospective migrant workers, in dealing with the government in obtaining work travel documents to the destination country. It strongly supports what was conveyed by Trochidis (2008) in Ginting, which said that in public services, it is necessary to develop a model of public service institutions that can make it easier for the public and the business world to deal with the government (Ginting et al., 2018). The government makes policies, and the aim is none other than to facilitate the community in resolving affairs, both between communities, a society with institutions, and society with the government. Therefore, with the existence of a one-stop integrated service system mandated by the Migrant Workers Act and is expected to be implemented in all local governments in Indonesia, the aim is to facilitate foreign job seekers or Indonesian migrant workers.

Indicators of the ease with which people receive public services are simple, straightforward, legal certainty, accurate, safe, responsible, complete facilities and infrastructure, easy access, discipline, polite and friendly, and comfortable. This indicator certainly requires a service strategy for local governments to create a service model in achieving convenience for the community. The bureaucratic system that has existed so far shows absolute authority due to a particular problem or community affair with the authorities, for example, the bureaucracy in processing passports. However, because services are made one roof, made simple, made easy, the existing bureaucratic system is trimmed. Of course, it is not easy to combine several authorities in one command.

In Tulungagung, the primary objective emphasized on each institution's authority holders is to provide easy and fast service to foreign job seekers. This is where a mutual agreement arises between authorities in government institutions to provide onestop integrated services. The purpose of this model is to simplify services to the community, both licensing and non-licensing. The management process starts with the application process for the publication of documents. This model is also mandated by Law number 18 of 2017 concerning the protection of Indonesian Migrant Workers. This service model is also by Ministerial Regulation (Permen) number 30 of 2015 concerning One-Stop 
Integrated Service (PTSA) at the Ministry of Manpower (Permenaker RI. No. 30 Tahun 2015 tentang PTSA, 2015).

\section{Conclusions}

The policy of the Tulungagung Regency government through the Office of Manpower and Transmigration (Disnakertrans) in creating a One-Stop Integrated Service (PTSA) policy model aims at making it easier for foreign job seekers or Prospective Indonesian Migrant Workers to obtain personal documents and travel documents quickly and safely. Although the Law on the Protection of Migrant Workers and the Ministerial Regulation (Permen) of Manpower has been enacted, it is not easy to implement at the technical level. The Regional Government, through the Head of Manpower and Transmigration Office, undertakes approaches and discussions to equate concepts and objectives for each authority holder, to achieve one main goal, namely to facilitate document issuance services for overseas job seekers.

This effort has proved quite effective so that overseas job seekers' services are getting more comfortable. Service data for 2017 shows that there are 11,225 services, and most of them are issuing A-1 Cards, issuing ID Carts for Prospective Migrant Workers, and issuing passports. The effectiveness of services ranging from licensing, services, implementation to the use of rights to one-stop integrated services carried out by the Tulungagung Regency government, and Operational Procedural Standards (SOP). As service users, foreign job seekers are helped and are no longer troubled by all requirements related to official documents stipulated by the government.

\section{References}

1. Asriani, D. D., \& Amalia, E. (2016). Jejak Perempuan Buruh Migran dalam Masyarakat ASEAN 2015. Jurnal Ilmu Sosial dan Ilmu Politik, 18(2), 147. https://doi.org/10.22146/jsp.13129

2. Bachtiar, P.P., Justin Sodo, R.J., Bima, L (2013). Pembelajaran dari Program Kinerja-USAID Penerapan Standar Pelayanan di Kota Singkawang, Kabupaten Luwu Utara, dan Kota Probolinggo: Pembelajaran dari Program. In Lembaga Penelitian Smeru (Palmira Pe, pp. 1-60). Jakarta: Lembaga Peneliti Smeru. Available at: https://www.neliti.com/publications/51142/penerapa n-standar-pelayanan-di-kota-singkawang-kabupatenluwu-utara-dan-kota-pro\#cite

3. Bank Indonesia. (2018). Laporan Perekonomian Indonesia ISSN 0522-2572. Available at: https://www.bi.go.id/id/publikasi/laporan/Documents 114 LPI2018.pdf
4. Cheng, H. (2016). On Migrant Workers' Social Status in Taiwan: A Critical Analysis of Mainstream News Discourse. International Journal of Communication, 10, 2509-2528. Retrieved from https://ijoc.org/index.php/ijoc/article/view/3905

5. Enggarani, N. S. (2016). Kualitas Pelayanan Publik dalam Perizinan di Pelayanan Terpadu Satu Pintu (PTSP) Kantor Badan Penanaman Modal dan Pelayanan Perizinan Terpadu (BPMP2T) Kabupaten Boyolali. Law and Justice, 1(1), 16. https://doi.org/10.23917/laj.v1i1.2702

6. Ginting, L. M., Susanti, E., \& Sumaryana, A. (2018). Implementasi Pelayanan Terpadu Satu Pintu NonPerizinan Di Ukur Dari Kepuasan Masyarakat Dengan Menggunakan Indeks Kepuasan Masyarakat. Responsive, 1(2), 45-55. Available at: http://jurnal.unpad.ac.id/responsive/article/view/2067 4

7. Herawati, N. (2010). Perlindungan dan Pemenuhan Hak-hak Ekonomi Buruh Migran Perempuan. Pamator Journal, 3(2), 122-127. https://doi.org/10.1371/journal.pone.0023789

8. Irawaty, T., \& Sri Wahyuni, E. (2015). Migrasi Internasional Perempuan Desa Dan Pemanfaatan Remitan Di Desa Pusakajaya, Kecamatan Pusakajaya, Kabupaten Subang, Provinsi Jawa Barat. Sodality: Jurnal Sosiologi Pedesaan, 5(3), 297-310. https://doi.org/10.22500/sodality.v5i3.9694

9. Ismayanti, L. (2015). Efektivitas Penyelenggaraan Pelayanan Terpadu Satu Pintu di Kabupaten Malang. JISIP: Jurnal Ilmu Sosial Dan Ilmu Politik, 4(2), 290-300.

10. Janesick. (1998). The Dance of Qualitative Research Design: Metaphor, Methodolatry, and Meaning. Sage Publications Ltd, 1(1), 35-59. https://doi.org/ISBN 0-7691-1435-8

11. Layaman, L., \& Hartati, S. (2009). Studi Efektivitas Pelayanan Publik di Kecamatan Kejaksan Kota Cirebon. Benefit Jurnal Manajemen Dan Bisnis, 1333. https://doi.org/10.23917/benefit.v12i1.1280

12. Liunsanda, J. A. (2019). Perlindungan Hak Asasi Manusia Terhadap Tenaga Kerja Indonesia Di Luar Negeri Ditinjau Dari Konvensi Ilo Tentang Buruh Migran. Lex Et Societatis, VII(5), 97-104. https://doi.org/10.1017/CBO9781107415324.004

13. Maryam, N. S. (2016). Mewujudkan good governance melalui pelayanan publik. Jurnal Ilmu Politik Dan Komunikasi, VI (1), 1-18. https://doi.org/10.34010/JIPSI.V6I1.232 
14. Mihradi, R. M., \& Siregar, F. M. (2017). Dinamika Problematika Sosial Perlindungan Buruh Migran Indonesia Pasca Reformasi Dan Relevansinya Dengan Tantangan Wirausaha Di Era Masyarakat Ekonomi Asean (Mea). Jurnal Kawistara, 7(2), 115 206. https://doi.org/10.22146/kawistara.23657

15. Moenir, H. A. S. (2010). Manajemen Pelayanan Umum di Indonesia. Manajemen Pelayanan Umum Di Indonesia.

16. Nola, L. F. (2016). Upaya Pelindungan Hukum Secara Terpadu Bagi Tenaga Kerja Indonesia (Tki). Negara Hukum, 7(1), 35-52. https://doi.org/https://doi.org/10.22212/jnh.v7i1.949

17. Ouyang, W., Wang, B., Tian, L., \& Niu, X. (2017). Spatial deprivation of urban public services in migrant enclaves under the context of a rapidly urbanizing China: An evaluation based on suburban Shanghai. Cities, 60, 436-445.

https://doi.org/10.1016/j.cities.2016.06.004

18. Permenaker RI. (2015). No. 30 Tahun 2015 tentang PTSA. Available at:

https://jdih.kemnaker.go.id/data wirata/wirata 19 2016.pdf

19. Rinda Paradista, M. (2019). Inovasi Ltsa Ptkln (Layanan Terpadu Satu Atap Penempatan Tenaga Kerja Luar Negeri) Di Dinas Tenaga Kerja Dan Transmigrasi (Disnakertrans) Kabupaten Tulungagung. Publika, 7(7), 1-7. Available at: https://jurnalmahasiswa.unesa.ac.id/index.php/publik a/article/view/31388

20. Rizal, R. M. (2008). Kebijakan Pelayanan Terpadu Satu Pintu (Ptsp) Melalui Pendekatan Sistem.

21. Sofiyan, R. (2018). Pengaruh Lingkungan Kerja Dan Kepuasan Kerja Terhadap Kualitas Pelayanan. Journal of Management Review, 2(3), 242. https://doi.org/10.25157/jmr.v2i3.1802

22. Suhayati, M. (2017). Pelaksanaan Perizinan Tenaga Kerja Asing Melalui Pelayanan Terpadu Satu Pintu Di Daerah. 55-83.

23. Sulaiman, A. I., Sugito, T., \& Sabiq, A. (2017). Komunikasi Pembangunan Partisipatif untuk Pemberdayaan Buruh Migran. Jurnal Ilmu Komunikasi, 13(2), 233. https://doi.org/10.24002/jik.v13i2.734

24. Sulistyowati, T. (2009). Makna Sosial dan Ekonomi Pekerja Migran Perempuan bagi Keluarga dan Masyarakat Desa (Studi di desa Kalipare Kabupaten Malang). Universitas Muhammadiyah Malang.

25. Sulistyowati, T. (2019). Model Adaptasi Pekerja Migran Perempuan dalam Mengkonstruksi Identitas
Sosial di Negara Tujuan. Jurna Perempuan Dan Anak, 2(1), 1-12. https://doi.org/ISSN 2442-2614

26. Suphanchaimat, R., Putthasri, W., Prakongsai, P., \& Tangcharoensathien, V. (2017). Evolution and complexity of government policies to protect the health of undocumented/illegal migrants in Thailand - The unsolved challenges. Risk Management and Healthcare Policy, 10, 49-62. https://doi.org/10.2147/RMHP.S130442

27. Taufik, A. I. (2014). Peran Asean Dan Negara Anggota Asean Terhadap Perlindungan Pekerja Migran. Jurnal Rechts Vinding: Media Pembinaan Hukum Nasional, 3(2), 255-280.

28. Undang-undang R.I. (2017). Undang-Undang Republik Indonesia NO. 182017 Tentang Perlindungan Pekerja Migran Indonesia.

29. Undang-undang R.I No. 18 Tahun. (2017). Tentang Perlindungan Pekerja Migran Indonesia.

30. Widodo, H., \& Belgradoputra, R. J. (2019). Perlindungan Pekerja Migran Indonesia. Bina Mulia, 8(1), 107-116. https://doi.org/10.37893/jbh.v8i1.42 